\title{
The demise of moderate Islam: new media, contestation, and reclaiming religious authorities
}

\author{
Wahyudi Akmaliah \\ Research Center for Society and Culture, Indonesian Institute of Sciences \\ (PMB-LIPI) \\ E-mail: wahyudiakmaliah@gmail.com \\ DOI: 10.18326/ijims.v10i1.1-24
}

\begin{abstract}
The landscape of the Indonesian public sphere-amidst the rise of new mediahas opened both opportunities and threats dealing with Islamic teaching. This condition shapes a danger for the two largest of moderate Muslim Organisations (Muhammadiyah and Nahdatul Ulama/NU), in which they do not engage much of the development of the digital platform. Consequently, dealing with religious issues, they become voiceless. By employing desk research with some relevant references and collecting information from social media, specifically Instagram and Youtube, this article examines the role of the Islamic organization of moderate Islam in the rapid digital platform as the new public sphere. The article finds that they have differences in responding to dealing with the presence of the new religious authorities. In comparison, while Muhammadiyah is more accepting of them calmly, $\mathrm{NU}$ is more reactively in responding.
\end{abstract}

Lanskap ruang publik Indonesia di tengah muncunya media sosial membuka kesempatan sekaligus ancaman terkait dengan dakwah Islam. Hal itu merupakan ancaman bagi dua organisasi besar Moderat Islam di Indonesia (Muhammadiyah 
dan NU), di mana mereka menjadi kelompok minoritas dalam aktivitas dakwah online. Akibatnya, berkaitan dengan issu-isu keagamaan, suara mereka menjadi tidak terdengar/didengarkan. Dengan melakukan riset studi literatur yang relevan dan informasi yang didapatkan dari akun media sosial, khususnya Instagram dan Youtube, artikel ini menjelaskan peranan organisasi Islam moderat di tengah cepatnya platform digital di ruang publik. Artikel ini menemukan bahwa Muhammadiyah dan NU memiliki respon yang berbeda terkait dengan kehadiran otoritas keagamaan baru. Sebagai perbandingan, penerimaan Muhammadiyah terhadap kehadiran mereka lebih biasa ketimbang dengan $\mathrm{NU}$ yang reaktif.

Keywords: Moderate Islam; 212 movement; New religious authorities; Social media

\section{Introduction}

The events of Islamic mobilization to insist that Basuki Tjahaya Purnama (Ahok) go to jail due to the accusation of the Al-Quran blasphemy on his speech in Kepulauan Seribu Jakarta on September 27 ${ }^{\text {th }}, 2016$ create the pivotal juncture on religious authority in Indonesia. Not only were the most significant events attended by a diversity of Indonesian Muslims but they were also questioning the presence of moderate Islam that has been dominated by the two largest Muslim organizations in years, Muhammadiyah and NU. Being well-known, both organizations formally appealed to their members not to join the events. There are some reasons why they asked them not to attend. ${ }^{1}$ Instead of following their instructions,

${ }^{1}$ For the PBNU Chairman, Said Agil Sirajd, the event was not understood very well for their members, so it was better to avoid and stay away from it, while the police officer had handled this case. Indeed, to strengthen this appealing, the PBNU's people issued the ban of Jum'at praying on the main road due to disturbing the interests of other public that employ it. For the Muhammadiyah Chairman, Haedar Nashir, the event was not only useless but also it had been exploited by the agenda of the Islamic radical group that tried to break the Islamic solidarity (Memecah Belah Umat). Republika.co.id, "PBNU Terbitkan Fatwa Larangan Salat Jumat di Jalan Raya”, in https://www.republika.co.id/berita/nasional/umum/16/11/24/ oh4wqf382-pbnu-terbitkan-fatwa-larangan-shalat-jumat-di-jalan-raya, accessed 1 July 2019; Okezone.com, "Tanggapi Aksi 212, Said Aqil: Boleh Ikut Tapi Jangan Bawa Atribut NU”, 
many of their members then joined the events while those demonstrations had continued at least five times, mainly November $4^{\text {th }}, 2016$, December $2^{\text {nd }}, 2016$, February 21 $1^{\text {st }}, 2017$, March $3^{\text {rd }}, 2017$, and May $5^{\text {th }}, 2017$.

In comparison to those demonstrations, the two events at the beginning were attended by the biggest Muslim organization, mainly November $4^{\text {th }}, 2016$, that was named the 411 movements and December $2^{\text {nd }}, 2016$, as the 212 movements. They also call these movements Aksi Bela Islam (Action to defense Islam). Due to these phenomena, some scholars have a different response. Burhani argues that the presence of the new religious authorities has fragmented the power, while the presence of Rizieq Shihab played a pivotal role in strengthening the evidence. ${ }^{2}$ Arifianto sees this issue within the internal rivalries of these organizations while undergoing the contestation on the level of their prominent figures dealing with the political electoral, whether in the local, national, and presidential election. ${ }^{3}$ Consequently, they do not have the same voices to articulate their public statements. However, the altering landscape of moderate Islam society to conservative turn has been alarming through Ricklefs with his extensive study on the historical reference of Islam in Java ${ }^{4}$ and Bruinessen's work by identifying the growth of the new Islamic organizations during and the

in https://news.okezone.com/read/2017/02/20/337/1623385/tanggapi-aksi-212-saidaqil-boleh-ikut-tapi-jangan-bawa-atribut-nu, accessed 1 July 2019. CNN Indonesia.com, "Muhammadiyah Imbau Masyarakat Tak Ikut Aksi 212", in https://www.cnnindonesia.com/ nasional/20170220084040-20194629/muhammadiyah-imbau-masyarakat-tak-ikut-aksi-212, accessed 1 July 2019.

${ }^{2}$ Ahmad Najib Burhani, "Plural Islam and Contestation of Religious Authority in Indonesia", in Islam in Southeast Asia: Negotiating Modernity, ed. Noorshahril Saat, Singapore: ISEAS, 2018.

${ }^{3}$ Alexander Arifianto, "Nadhlatul Ulama is home to its own hardliners", New Mandala, (8 August 2018), in http://www.newmandala.org/nadhlatul-ulama-home-hardliners/, accessed 2 July 2019.

${ }^{4} \mathrm{MC}$. Ricklefs, Islamisation and Its Opponents in Java: A Political, Social, Cultural and Religious History, c. 1930 to Present, Singpore: NUS Press, 2012. 
post-authoritarian regime comprehensively. ${ }^{5}$

Undoubtedly, these conditions force us to look back on Hefner's work that previously predicted more optimism on the future of Indonesian political Islam that was broadly compatible with democracy and religious pluralism. ${ }^{6}$ This idea was inspired by Intellectual Muslim figures that could combine both Islamic knowledge tradition and its theology as well as modern western theory, such as Nurcholish Madjid, Dawam Rahardjo, and Abdurrahman Wahid. Not only does the foundation explain the Indonesian Muslim society, but this thesis also becomes "a leading framework adopted by scholars and policymakers alike to analyze Islam in Indonesia during the post-Reformasi period." 7 Therefore, some critics revisit Hefner's works by redefining the willingness of both Muhammadiyah and NU as "policy intervention that is driven more by internal factors than by an ideological commitment to the civil Islam." Additionally, there is an ambiguity of the organizations that are supporting the Indonesian democratic transition and its consolidation. However, at the same time, they also create "the ally with the anti-democratic actors to combat blasphemy against Islam, nonMuslim speech on matters about the Islamic faith and non-Muslim political control over majority-Muslim regions of Indonesia." 8 Meanwhile, Arifianto specifically criticizes Hefner's methodology of choosing the informants that are from the Muslim intellectual elites who had developed very well on the combination of Islamic tradition knowledge and modern western theory. ${ }^{9}$

\footnotetext{
${ }^{5}$ Martin Van Bruinessen, Contemporary Developments in Indonesian Islam, Explaining the Conservative Turn, Singapore: ISEAS, 2013.

${ }^{6}$ Robert W. Hefner, Civil Islam: Muslim and Democractization in Indonesia, Pricenton: Princenton University Press, 2000, 218.

${ }^{7}$ Gustav Brown, "Civic Islam: Muhammadiyah, NU and the Organisational Logic of Consensus-making in Indonesia”, Asian Studies Review, vol. 43, no. 2 (2019), 1-18.

${ }^{8}$ Jeremy Menchik, "Moderate Muslim and Democractic Breakdown", Asian Studies Review, vol. 43, no. 2 (2019), 415-433.

${ }^{9}$ Alexander Arifianto, "Quo Vadis Civil Islam? Explaining Rising Islamism in PostReformasi Indonesia”, in https://kyotoreview.org/issue-24/rising-islamism-in-post-reformasi-
} 
This article differentiates these previous critics by examining the role of both organizations amidst the rise of new media that has opened both the opportunity and threat dealing with Islamic teaching (dakwah) in Indonesia. Regarding the digital technology and Islamic proselytization, some scholars have discussed, ${ }^{10}$ though are, the role of Muhammadiyah and NU in this field. Examining their role in social media contributes significantly to why their voices could not be listened to on the series of Islamic mobilizations, locating themselves as the minority groups in the online activities. The three questions propose to deal with this context: how do they respond to Islamic teaching in the digital platform? In what ways do the new religious authorities play their pivotal role in attracting their new Islamic audiences? Comparing both Muhammadiyah and Nahdatul Ulama, how is the future projection on the path of moderate Islam within the context of the digitalization of Islamic teaching amidst the conservative turn in Indonesian Muslim society? This article argues that the new media creates anxiety within their organization members, impacting the different responses.

indonesia/, accessed 25 June 2019.

${ }^{10}$ Birgit Bräuchler, "Cyber identities at war: religion, identity, and the Internet in the Moluccan conflict", Indonesia 75 (2003), 123-151; Merlyna Lim, "Archipelago Online: The Internet and Political Activism in Indonesia", Doctoral Dissertation. University of Twente, The Netherlands, 2005; Bart Barendregt, "Mobile Religiosity in Indonesia: Mobilized Islam, Islamized Mobility and the Potential of Islamic Techno Nationalism", in Erwin Alampay (ed.), Living the Information Society in Asia, Singapore: ISEAS, 2009, 73-92; Nadirsyah Hosen, "Online Fatwa in Indonesia: From Fatwa Shopping to Googling a Kiai", in Greg Fealy and Sally White (eds.), Expressing Islam: Religious Life and Politics in Indonesia, Singapore: ISEAS, 2008, 159-173; Martin Slama, "A subtle economy of time: Social media and the transformation of Indonesia's Islamic Preacher Economy", Economic Anthropology, 4 (2017), 94-106; Acep Muslim, "Digital Religion and Religious Life in Southeast Asia: the One Day One Juz (ODOJ) Community in Indonesia", Asianscape: Digital Asia, 4 (2017): 33-51; Eva F. Nisa, "Creative and Lucrative Da'wa: The Visual Culture of Instagram amongst Female Muslim Youth in Indonesia”, Asiascape: Digital Asia, 5 (2018), 68-99; Emma Baulch and Pramiyanti Alilla, "Hijabers on Instagram: Using Visual Social Media to Construct the Ideal Muslim”, Social Media + Society, (2018),1-15. 


\section{Feeling threatened on Islamic preachers online}

By employing the concept of feeling threatened in Mujiburrahman's work, ${ }^{11}$ this part describes the responses of both Muhammadiyah and NU that I explain in the variety of the events as the representation dealing with the presence of online preachers and the new Islamic teaching in the digital platform. To begin, I started with my personal experience dealing with Muhammadiyah's response. On May 27 $7^{\text {th }}, 2018$, I was invited by the Central Board (Pimpinan Pusat) of Muhammadiyah in the Islamic teaching of Ramadhan $(1439 \mathrm{H})$ to talk about Virtual Islam and the variety of Da'wah Digital contemporary.

During the session of Questions and Answers, a woman in her 50s, coming from the Aisyiyah boards, one of the organizations under the formal structure of Muhammadiyah, expressed her anxiety about the emergence of new Islamic preachers, employing the digital platform as the Islamic proletarianization massively. Muhammadiyah still establishes TVMU (Muhammadiyah's Television) as the medium of da'wah to catch up with the others of da'wah-entertainment delivered by many private televisions. According to her, many signs of progress had been improved by the TVMU on the quality programs. These conditions create a possibility to compete with the most prominent company of private television by offering the Islamic vision through Muhammadiyah's perspective. Nevertheless, their

\footnotetext{
${ }^{11}$ Through historical background during the two periods of the Indonesian presidency, mainly Sukarno and Suharto, Mujiburrahman explains how Muslim-Christian relations in Indonesia that caused mutual suspicion among them through the government policy. For the Muslims group, the presence of Christian with the agenda of Christianisation as well as government support through the plans was the way to alter the Indonesian Muslim populations. Meanwhile, for them, to establish the Islamic state would create them to be the second citizen in Indonesia, creating them then to be allied with the group of the military during the Suharto presidency. This condition then shaped feeling threatened among them, though the programs of interfaith dialogue, organized by some of NGOs, tried to reconcile them. Mujiburrahman, Feeling Threatened: Muslim-Christian Relations in Indonesia's New Order, Amsterdam: Amsterdam University Press, 2006.
} 
existence as the new agency of Islamic preaching forces Muhammadiyah's members to rethink and renew their da'wah methods.

The same feeling is happening to the members of NU that respond reactively through some events. In the name of saving the Indonesian nationalism and the hate speech prevention on the name of the infidel, and fight against khilafah, the NU' members have structurally and culturally objected to some of the popular online preachers to deliver their Islamic teaching. First is the rejection of Hamid Basalamah to provide Islamic education in some of the places, such as in Lamongan, Sidoarjo, and Jakarta. ${ }^{12}$ Second, it is Felix Siauw's objection to the Islamic teaching in some of the Indonesian provinces. The Waqaf Body Foundation of Sultan Agung in Semarang invited him to deliver the Islamic teaching on July $9^{\text {th }}$, 2017. Nevertheless, most of the Nahdatul Ulama of autonomous organizations-mainly Banser NU, PMII, IPNU, Ganaspati, and Patriot Garuda Nusantara-refused him. Not only because of his position as the religious teacher of HTI that raised suspicions about him forming the campaign of anti-Pancasila and anti-NKRI, but his presence could also cause anxiety and a horizontal conflict. ${ }^{13}$ A similar event was happened in the Mosque of Al-Ikhlas in Lamongan, East Java, though he finally insisted on delivering an Islamic speech on June $27^{\text {th }}, 2019 .{ }^{14}$ In another

${ }^{12}$ Duta Islam, "Provokatif, Ceramah Khalid Basalamah Ditolak Umat Islam Lamongan", in https://www.dutaislam.com/2016/09/provokatif-ceramah-khalid-basalamah-ditolakumat-islam-lamongan.html?hl=in_ID, accessed 16 July 2019; Nu Online, "Ini Penyebab Ceramah Khalid Basalamah Ditolak di Sidoarjo", in http://www.nu.or.id/post/read/75865/ ini-penyebab-ceramah-khalid-basalamah-ditolak-di-sidoarjo-, accessed 16 July 2019; CNN Indonesia, " GP Ansor Tolak Ceramah Ustaz Khalid di Masjid Hasyim Asyari”, in https:// www.cnnindonesia.com/nasional/20180505105126-20-295900/gp-ansor-tolak-ceramah-ustazkhalid-di-masjid-hasyim-asyari?, accessed 16 July 2019.

${ }^{13}$ Kumparan.com, "Tanggapan Felix Siauw Ditolak 5 Ormas di Semarang”, in https:// kumparan.com/@kumparannews/tanggapan-felix-siauw-ditolak-5-ormas-di-semarang, accessed 16 July 2019.

${ }^{14}$ Tribunnews.com, "Ditolak Keras Salah Satu Ormas Terbesar, Felix Siauw Curhat Saat Hadir di Ponpes Al-Ikhlas Lamongan”, in https://www.tribunnews.com/ 
month, his Islamic teaching were also suddenly canceled by the committee of Fatahillah Mosque located in the Jakarta governor building while he was previously allowed many Islamic teaching activities. ${ }^{15}$

Third, it is the rejection of Hanan Attaki, who was attending Islamic teaching that was planned in the hotel of Bahari Inn, on July $7^{\text {th }}, 2019$. The main reason why Imam Kharomaeni, as the local leader of GP Ansor, refused him by sending the objection letter to the Chief of Local Police Officer, was due to his Islamic teaching containing the provocative value. For him, some of the provocative content of Hanan Attaki's Islamic teaching was, he argues, that Prophet Moses is the goon among the prophets. ${ }^{16}$ However, unlike the two objections, this protest has been responded to differently by the internal of NU's members. One of them is Akhmad Sahal, for whom Hanan Attaki's Islamic teaching is different and could not be invited for the radicalism thought and spreading the slander. Due to this objection through his twitter account on July $8^{\text {th }}, 2019$, he should undergo a tension among the NU's members who are involved in the opposition on Hanan Attaki's presence in Tegal. Undoubtedly, comparing the two of Islamic preachers, Hanan Attaki's dakwah is different, approaching the youth spirit in the subculture practices and adjusting into the social media platform.

Following the explanation above, one question remains: why are these organization members feeling threatened while on the level of members, infrastructure, human resources with the long periods are enormous?

regional/2019/06/28/ditolak-keras-salah-satu-ormas-terbesar-felix-siauw-curhat-saat-hadir-diponpes-al-ikhlas-lamongan, accessed 16 July 2019.

${ }^{15}$ Detik.com, "Felix Siauw Bicara Soal Kajiannya Yang Dibatalkan Pemprov DKI", in https://news.detik.com/berita/d-4600270/felix-siauw-bicara-soal-kajiannya-yang-dibatalkanpemprov-dki, accessed 16 July 2019.

${ }^{16}$ Kumparan, "Kronologi Penolakan Ustaz Hanan Attaki di Tegal oleh GP Ansor", in https://kumparan.com/panturapost/kronologi-penolakan-ustaz-hanan-attaki-di-tegal-olehgp-ansor-1rQGcF7kxIM, accessed 16 July 2019. 
Muhammadiyah has an internal infrastructure that is commonly called AUM (Amal Usaha Muhammadiyah/Muhammadiyah Entrepreneurial Activities) that consists of four group activities. In detail, for educational activities, Muhammadiyah has 4.623 kindergartens, 2.252 elementary schools, 1.111 middle schools, 1.291 high schools, 71 the extraordinary schools (SLB), 67 Islamic boarding Schools (Pesantren), 171 colleges and universities. For health services that consist of hospitals, clinics, and maternity and pediatric in total, they have 2.119. Meanwhile, they have 525 of social welfare that consists of the orphanage, nursing home, and disabled rehabilitation. Lastly, for property ownership, they have 5.080 small mosques (Mushola), 6.118 Mosques, and land with a length of 20.945.504 $\mathrm{M}^{2}{ }^{17}$ For NU, they have 28. 958 kindergartens, 59.650 the group of Majelis Taklim, 99 universities, 23.000 Islamic boarding schools, and 30 hospitals. ${ }^{18}$

This amount will surely grow bigger due to the many NU's members having their own infrastructures written as part of NU's infrastructure officially. On the other hand, although they have different opinions, both NU and Muhammadiyah members are the biggest in Indonesia, compared with other Islamic organizations. As explained by Hasanuddin Ali through his research within the Alvara Research Center, it is estimated that the Indonesian Muslim who affiliated with NU is 79,04 of millions of people while those who are joining with Muhammadiyah are 22,46 millions of people, ${ }^{19}$ though previously Bush predicted in 2014 that the members of NU were $49 \%$ and Muhammadiyah, only $7,9 \%$ from the

\footnotetext{
${ }^{17}$ Muhammadiyah, "Data Amal Usaha Muhammadiyah", in http://www.muhammadiyah. or.id/id/content-8-det-amal-usaha.html, accessed 17 July 2019.

${ }^{18}$ NU Online, "Inilah Puluhan Ribu Amal Usaha Muslimat NU”, in http://www.nu.or. $\mathrm{id} /$ post/read/52377/inilah-puluhan-ribu-amal-usaha-muslimat-nu, accessed 17 July 2019.

19Hasanuddin Ali, "Menakar Jumlah Jamaah NU dan Muhamamdiyah" in https:// hasanuddinali.com/2017/01/19/menakar-jumlah-jamaah-nu-dan-muhammadiyah/, accessed 17 July 2019.
} 
total of the Indonesian population. ${ }^{20}$ However, the presence of the new religious authorities in New Media, especially in social media, and Islamic websites give them to enlarge their voices, impacting the Indonesian public sphere's attention." ${ }^{21}$

\section{The rise of the new religious authorities}

The presence of the new media with the current modes of communication has altered the landscape of the existence of the religious authorities' establishment, causing a disruption within the society. In the Muslim world, it situates the "fragmenting and contesting political and religious authority," between the old and the new one. ${ }^{22}$ The use of the internet as Islamic proselytization has faced the appropriation following the development of the digital platform, especially social media. In comparison to both Muhammadiyah and NU, many Islamic groups, whether the new and the old ones, have employed new media. Consequently, amidst the growth of the Indonesian population, especially Muslim society and the

\footnotetext{
${ }^{20}$ Robin Bush, "A Snapshot of Muhammadiyah Social Change and Shifting Markers of Identity and Values", Asia Research Institute, Working Paper Series No. 221, 2014.

${ }^{21}$ The growth of Internet users in Indonesia every year, and smartphone ownership strengthens the factor. According to APJII (Asosiasi Penyelanggara Jasa Penyelenggara Internet Indonesia/Indonesia Internet Service Provider Association), the rise of the Internet users is significant while it increases $10,2 \%$ with the 27.916 .716 of people from 2017 to 2018. In 2017, the figures of the user were 143, 26 of millions $(54,68 \%)$, while it gains 171,17 of millions of people $(64,8 \%)$ from the total of the Indonesian population, 264,16 of millions. This number of people then bridge the gap between the urban and the rural area. In the metropolitan area, most of the Indonesian access the Internet with a percentage of $74,1 \%$ while it is $61,6 \%$ of the users from the rural area. Most of them, with a portion of $93,9 \%$ access the Internet through smartphones in daily life activities. These figures represent what Merlyna Lim argues on the Internet activity as Cyber-Urban Space, reflecting on "where contemporary urban people live much of the time, juggling multiple identities that transcend online and offline spheres." On the other hand, as she suggests previously, "much of the early work dichotomized online/cyber/virtual life and offline/real/physical life. Merlyna Lim, "Cyber Urban", In Anthony M Orum (ed), The Wiley Blackwell Encyclopedia of Urban and Regional Studies, New Jersey: Wiley Blackwell, 2019.

${ }^{22}$ Merlyna Lim, "Archipelago Online: The Internet and Political Activism in Indonesia", Doctoral Dissertation, University of Twente, The Netherlands, 2005, 14-15.
} 
The demise of moderate Islam: new media, contestation, and reclaiming religious... (Wahyudi Akmaliah)

development of the Internet users, they have been left behind-replaced with the new of these religious authorities, individually and collectively. For a positive reason, their presence democratizes all of Indonesian Muslims to choose the Islamic reference from the website that they tend to like. To some extent, they challenge the Indonesian foundation, mainly Pancasila as the form of nationality integration in Indonesia and, on the other hand, they propose the Islamic trans-ideology in the name of Ummah, the Islamic state, and the conservative tone tendency. By employing the Alexa and Similiar Web as the website to rank various websites in the world, Pusat Studi dan Perubahan Sosial (PSPS), Muhammadiyah University of Solo finds an exciting result on Islamic websites. They argue that many Islamic websites are predominantly those Islamic forms in 2017 as a part of the new religious authorities. Ironically, both Muhammadiyah and NU could not compete with them.

Table 1. The comparison of Islamic organization Website Rank based on Alexa and Similarweb ${ }^{23}$

\begin{tabular}{|l|l|l|l|l|l|}
\hline Website & $\mathbf{9}$ October 2017 & $\mathbf{2 9}$ October 2017 & Website & National & Global \\
\hline portal-islam.id & 473 & 463 & Eramuslim.com & 489 & 22,825 \\
eramuslim.com & 615 & 581 & Portal-islam.id & 532 & 26,416 \\
nu.or.id & 784 & 705 & Nu.or.id & 959 & 42,312 \\
hidayatullah.com & 1,159 & 1,025 & voa-islam.com & 1,155 & 49,820 \\
voa-islam.com & 1,332 & 1,328 & hidayatullah.com & 1,322 & 51,188 \\
dakwatuna.com & 1,555 & 1,475 & dakwatuna.com & 2,403 & 100,063 \\
muslimmoderat.net & 3,543 & 3,470 & arrahmah.com & 3,480 & 137,489 \\
arrahmah.com & 3,061 & 4,646 & muslimmoderat.net & 3,910 & 143,135 \\
suara-islam.com & 5,375 & 6,281 & suara-islam.com & 8,413 & 269,714 \\
suaramuhammadiyah.id & 8,629 & 8,198 & suaramuhammadiyah.id & 15,222 & 577,632 \\
mta.or.id & 22,335 & 21,566 & mta.or.id & 32,548 & $1,027,581$ \\
dewandakwah.or.id & 195,912 & 100,146 & nw.or.id & 167,351 & 496,207 \\
Majelismujahidin.com & 116,662 & 118,415 & Thoriquna.id & 444,084 & $6,613,736$ \\
nw.or.id & 135,276 & 177,611 & Majelismujahidin.com & 525,425 & $1,618,158$ \\
& & & dewandakwah.or.id & 588,149 & $10,09,582$ \\
& & & & & \\
\hline
\end{tabular}

${ }^{23}$ M. Thoyibi and Yayah Khisbiyah, Kontestasi Wacana Keislaman di Dunia Maya: Moderatisme, Ekstremisme, dan Hipernasionalisme, Solo: Pusat Studi dan Perubahan Sosial UMS, 2018, 91-99. 
Through table 1, in the rank of Alexa ad Similiarweb, both NU (nu. or.id) and Muhammadiyah (suaramuhammadiyah.id) take the position in the number of three and ten. Meanwhile, those of Islamic website is dominating in the public online such as portal-Islam.id, eramuslim.com, hidayatullah, voa-islam.com, dakwatuna, and arrahmah.com. In other words, to understand something related to the practices of Islam through Google index, those of Islamic websites will be found by the largest Indonesian Muslim audience. Not only is so much information with Islamic material following their Islamic ideologies added, but their material resources have also become strong keywords, impacting the structure of algorithm in the Google search adjusting people's references. This google algorithmic will provide much information that strongly relates to their preferences. In some of the crucial issues, such as both religion and political tension, the Indonesian Muslims' choices will come into the algorithmic enclaves adjusting to their political and religious interests. It is happening in the Jakarta election, as explained by Merlyna Lim, leading people into prison for their opinion based on their preferences. ${ }^{24}$ Therefore, the main reason why both Muhammadiyah and NU followers do not want to listen is that their appeal to involve in the series of Islamic mobilization in the case of Ahok's accusation blasphemy could be explained within this argument.

Regarding those Islamic websites, we could not generalize them into one category due to diverse forms of their content. Savic Ali's observation is the essential factor in understanding their backgrounds while he divides into the four categories on Islamic websites, including both the websites of Muhammadiyah and NU. First, the ultra-conservative Islamic website creates the school of Islamic thought with the Salafi and Wahabi ideologies, proposing the Islamic orthodoxy, such as almanhaj.or.id and muslim.or.id.

\footnotetext{
${ }^{24}$ Merlyna Lim, "Freedom to hate: social media, algorithmic enclaves, and the rise of tribal nationalism in Indonesia”, Critical Asian Studies, vol. 49, no. 3 (2017), 411-427.
} 
Some of their characteristics are the prohibition of music, without women's pictures, and Islamic regulations dealing with sculpture in the home. Second, the content of Islamic politics that is in the form of ummah advocacy, such as eramuslim.com and voa-islam.com. Not only do these Islamic websites contain the oppression of Islam in the world, colonized by the West like the US and Europe representation, but they also narrate on the triumph of Islam in history to provoke their solidarity of ummah. Previously, many of their writers are the former of Sabily magazine journalists. Third, the representation of Multiculturalism is the form of moderate Islamic websites such as nu.or.id and suaramuhammadiyah.id. Finally, they are Islamic websites that gain commercial benefits through Google AdSense. ${ }^{25}$

Meanwhile, on social media, especially on the Youtube channel, these new religious authorities are predominantly influencing the Indonesian public online, mostly coming from the Islamic stream of both Salafi and Wahabi, such as Yufid TV, Rodja TV, and Ammar TV. Meanwhile, both Muhammadiyah and NU are represented by tvMu, Aswaja Tube, NU Channel, and NU TV. According to Ibnu Nadzir, ${ }^{26}$ both Salafi and Wahabi channels are more significant in terms of the numbers of subscribers,

\footnotetext{
${ }^{25} \mathrm{Ahmad}$ Zaenuddin, "Kompetisi di antara berbagai situsweb Islam”, in https://tirto.id/ kompetisi-di-antara-berbagai-situsweb-islam-cEHi, accessed 17 July 2019.

${ }^{26}$ Furthermore, he explains that Yufid TV has the 491.866 of subscribers with the number of video content upload, mainly 7568 of the contents and the average contents monthly 91 videos, followed by the Rodja TV with the 136.668 of subscriber numbers and 1147 of the video contents and monthly average 16 videos. Ammar TV has taken a position in the third largest with the 405.345 of subscribers and 1047 of video contents, and the average of video monthly 27 items. On the other hand, tvMu is the highest rank among the other Islamic moderate channel with the 7.173 subscribers and the 2097 of the video contents with the average monthly 45 videos, followed by Aswaja Tube in the second number with the 47.324 of subscribers and the 992 of the videos, while every month on average is 19 videos uploading. Both NU Channel and NUTV in the fourth and fifth position with 349 and 2.761 of subscribers and 23-314 of the content videos in the average content between 8-11 videos monthly. Ibnu Nadzir, "Da'wa 2.0: The Mediation of Preaching on Salafi's Internet Practices", paper presented on the conference "Religious Authority in Indonesian Islam: Contestation, Pluralization, and New Actors”, ISEAS-Yusuf Ishak, Singapore, 3-4 July 2018.
} 
IJIMS: Indonesian Journal of Islam and Muslim Societies, Volume 10, Number 1, June 2020: 1-24

content, and the average content monthly, surpassing the channels of both Muhammadiyah and NU.

Table 2. Islamic Religious Authorities on Youtube Channel ${ }^{27}$

\begin{tabular}{cccccc}
\hline No & Channel & $\begin{array}{c}\text { Number of } \\
\text { Subscriber }\end{array}$ & First Upload & $\begin{array}{c}\text { Number } \\
\text { Contents }\end{array}$ & $\begin{array}{c}\text { Average } \\
\text { content } \\
\text { per } \\
\text { month }\end{array}$ \\
\hline 1 & Yufid TV & 491.866 & 1 March 2011 & 7568 & 91 \\
2 & Rodja TV & 136.668 & 26 January 2012 & 1147 & 16 \\
3 & Ammar TV & 405.345 & 8 November 2014 & 1067 & 27 \\
4 & tvMU & 7.173 & 31 March 2014 & 2097 & 45 \\
5 & Aswaja Tube & 47.324 & 9 October 2013 & 992 & 19 \\
6 & NU Channel & 349 & 21 November 2017 & 23 & 8 \\
7 & NUTV & 2.761 & 15 September 2015 & 314 & 11 \\
\hline
\end{tabular}

On Instagram, these new religious authorities are also influenced primarily by their followers. The chosen Instagram as their Islamic proselytization could definitely be explained on the target audience, while most of Youth Muslim in the age group of 15-30 years. Among them is Abdul Somad as the highest of followers on Instagram with the 9, 7 million, though his account has disappeared and been replaced with the new one, @ustadabdulsomadofficial. Hanan Attaki takes the second position with the 7, 4 millions of followers, followed by Felix Siauw and Adi Hidayat, with 4 million and 2 million followers, respectively. Both Khalid Basalamah and Syafiq Riza Basalamah are in the middle positions with 999.000 followers and its 933.000 members. The last rank has been achieved by Handy Bony and Evie Efendi that consist of 324.000 followers

\footnotetext{
${ }^{27}$ Ibnu Nadzir, "Da'wa 2.0: The Mediation of Preaching on Salafi's Internet Practices", paper presented on the conference "Religious Authority in Indonesian Islam: Contestation, Pluralization, and New Actors”, ISEAS-Yusuf Ishak, Singapore, 3-4 July 2018.
} 
and 16,600 followers.

Table 3. The Amount of New Religious Authorities' Followers on Instagram

\begin{tabular}{clll}
\hline No & \multicolumn{1}{c}{ Instagram Account } & \multicolumn{1}{c}{ Name } & \multicolumn{1}{c}{ Followers } \\
\hline 1 & @ustadzabdulsomad & Abdul Somad & 9,7 million \\
2 & @hanan_attaki & Hanan Attaki & 7,4 million \\
3 & @felixsiauw & Felix Siauw & 4 million \\
4 & @ustadadihidayat & Adi Hidayat & 2 million \\
5 & @halidbasalamahofficial & Khalid Basalamah & 999 thousand \\
6 & @yafiqrizabasalamah_official & Syafiq Riza Basalamah 933 thousand \\
7 & @oemar_mita & Oemar Mita & 698 thousand \\
8 & @handy.bonny & Handy Bonny & 324 thousand \\
9 & $@$ evieefendie & Evie Efendie & 16.6 thousand \\
\hline
\end{tabular}

The provided information explains that the new religious authorities command the Indonesian public sphere in the new media that consists of three factors. They are the Islamic website, audio-visual through Islamic videos on Youtube, and Instagram as the highest of Indonesian youth users on the platform of social media. In comparison to the previous Islamic proselytization through the print media, television, radio, and cassette that need more the capitalist economy to build, the new media-as an Islamic preaching medium-could be economical. It causes them to emerge into the Indonesian public sphere vastly. Both consistency and innovation are other factors that are successful in attracting the Indonesian Muslim people.

Also, the quality of visual aesthetics and communication approach is humble and interactive and encourage people to watch, subscribe, and follow. The strategy of good marketing they employ by adjusting to the background of their audience target is another factor to consider. Through their Islamic proselytization, Indonesian public Islam has been reshaped, causing to redefine Indonesian Islam. Not only is Indonesian Islam driven through their 
perspective, but the power of the new media in their hands also enforces the position of moderate Indonesian Muslims that previously had the optimism in the future as Hefner's word predicted. Sadly, the power of their social media amplification could create the unholy allies with the politico-entrepreneur. The two cases with different results are exemplary, mainly the Jakarta election (2017) as a success to defeat Ahok, who is the incumbent of Jakarta governor through the exploitation of religious sentiments and the failure of the presidential election (2019) to win Prabowo. This was to replace Jokowi as the Indonesian president in the first term (2014-2019).

\section{Conclusion}

The influence of the new religious authorities creates the feeling of threat, as explained earlier. Although both NU and Muhammadiyah have the same awareness, they respond differently. While Muhammadiyah acknowledges it calmly, NU responds to it reactively. Admittedly, there are many aspects behind their different responses. Islamic ideology background, the environment of structure organization, and the basis of their members are geographically the three factors that I would like to explain within this discussion by providing the two perspectives on these organizations.

The words of Abdul Mu'ti, Muhammadiyah Secretary-General, on the presence of Hijrah Fest activities organized by these new religious authorities could be a reference to understanding Muhammadiyah's response. For him, the presence of the new religious authorities through social media, as well as hijrah fest, is an interesting socio-religious interesting phenomenon. It becomes a positive trend and the new stream of the Islamic movement, specifically following the previous trend that was hype in the past. There were, for instance, such as Ari Ginanjar with the ESQ Training and Yusuf Mansur with one day one ayat and its religious meal (sedekah) movement. Due to the only trend, they could not be the mainstream of Islamic movement, except they have influential prominent 
figures consistently. ${ }^{28}$ However, he sets the alarm softly for those Muslims who are studying Islam in the digital application, given that many Islamic teachings on social media do not give clear references, no Islamic teacher who guides them. They also provide a limited time of around 2-5 minutes. Consequently, they will get the wrong information and, furthermore, it could cause new problems. ${ }^{29}$

Therefore, instead of employing social media, Muhammadiyah prefers to choose the conventional way for young Muslims to understand and to study Islam by meeting up personally. For him, practicing Islamic proselytization will traditionally obtain the deep meaning, and the material content could be responsibly compared to learning Islam via social media. Therefore, for him, Muhammadiyah is different from the Islamic teaching approach. Although on the level of prevention of Islamic teaching, Muhammadiyah still prepares it knowing that they have discussed it internally. According to Benni Setiawan, the members of the leadership center Muhammadiyah cadre committee, some of Muhammadiyah universities have gotten a job in their contribution to handling some issues. He argues that they should establish the big data, aiming to understand and to map out the Muhammadiyah members in all of the Indonesian provinces. Indeed, Haedar Nashir, the chairman of Muhammadiyah has invited the two of Muhammadiyah cadres who have expertise in this issue. In many moments, Haedar has often reminded the Muhammadiyah cadres to establish the centers of excellence, especially having the big data as the center of digital Islamic proselytization. ${ }^{30}$

\footnotetext{
${ }^{28}$ Republika.co.id, "Mu'ti: Hijrah Fest Fenomena Sosial Keagamaan Yang Menarik", in https://www.republika.co.id/berita/dunia-islam/islam-nusantara/18/11/12/pi2hxl384-mutihijrah-fest-fenomena-sosial-keagamaan-yang-menarik, accessed in 18 July 2019.

${ }^{29} \mathrm{CNN}$ Indonesia, "Anak Muda Hijrah di mata NU dan Muhammadiyah", in https:// www.cnnindonesia.com/nasional/20190516190532-20-395594/anak-muda-hijrah-di-matanu-dan-muhammadiyah, accessed in 18 July 2019.

${ }^{30}$ Benni Setiawan, "Dakwah Pencerahan Era Digital”, in https://investor.id/archive/
} 
As a result, Muhammadiyah creates the application in the play store, such as TVM $u$ for the online television, Tarjih as the digital of praying guideline and Islamic law content in Muhammadiyah's perspective, Muvon for the application in order to live with the halal life, and Edumu for the material studies in Muhammadiyah's curriculum system, and messenger $\mathrm{M} u$ for the communication and online chatting. ${ }^{31}$ On the Islamic website, there are 64 websites that are affiliated with Muhammadiyah. ${ }^{32}$

For Dadang Kahmad, these ways on how Muhammadiyah should involve the popular Islamic preacher instantly, while many of their Islamic resources could not be yet responsible-it is also considered Muhammadiyah's challenges. By creating these Islamic digital products through the apps, he hopes that Islamic preachers from Muhammadiyah do not often come to many places. Still, they could employ social media to gain many Indonesian young people largely. ${ }^{33}$

Although the digital dakwah is the part of response on the new religious authorities, those products mostly deliver to the Muhammadiyah members in Indonesia, instead of resisting the rise of new Islamic actors. It seems that Muhammadiyah tries to avoid the conflict compared to a face-to-face fight with these new Islamic authorities. Nevertheless, establishing the front of the Islamic website, generally in the sense of Muhammadiyah, has been a struggle for some of Muhammadiyah's young militant cadres. They have previously been involved in social activities for years. The emergence of

dakwah-pencerahan-era-digital, accessed 16 July 2019.

31Republika.co.id, "Sasar Milennial, Muhammadiyah Perkuat Konten Dakwah Digital", in https://khazanah.republika.co.id/berita/dunia-islam/islam-nusantara/19/02/15/pmz1ly320sasar-milenial-muhammadiyah-perkuat-konten-dakwah-digital_accessed in 18 July 2019.

${ }^{32}$ Pimpinan Wilayah Muhammadiyah Jawa Timur, Daftar Website Terafiliasi Persyarikatan Muhammadiyah", in https://pwmu.co/daftar-website-terafiliasi-persyarikatanmuhammadiyah/, accessed in 18 July 2019.

33Republika.co.id, "Sasar Milennial, Muhammadiyah Perkuat Konten Dakwah Digital", in https://khazanah.republika.co.id/berita/dunia-islam/islam-nusantara/19/02/15/pmz1ly320. sasar-milenial-muhammadiyah-perkuat-konten-dakwah-digital, accessed in 18 July 2019. 
Ibtimes.id as the new Islamic website is one of those. Content, whether on the level of the quality and quantity, should improve to attract most of the Indonesian Muslim viewers.

In my argument, between Muhammadiyah and these new religious authorities, there is a similar ideology and a base of their followers geographically. Inspired by Ibn Taymiyah (1263-1328) as an Islamic theologian, Muhammadiyah has been struggling to purify the Islamic faith by practicing the dakwah method, such as an unforgiving attitude towards takhayyul (superstition), bid'ah (innovation) and churafat/ khurlfah (unorthodoxy). Those are not historically evident with the Islamic tradition and the two primary resources, mainly Al-Quran and Hadits. Besides, this organization has also been inspired by Muhammad Abduh (1849-1905), to rationalize and to modernize their religious belief within education ${ }^{34}$ through the establishment of many schools, and universities in all Indonesian provinces.

While most of the new religious authorities adopt their Ideological aspirations from the Islamic organizations and their prominent figures, they have many similarities with the apparent differences in many aspects. The place geographically consists of urban areas. This is another argument to understand their basic similarities on the base of their followers. Hence, the resistance of these new figures could not work reactively. The characteristic organization with the social administrations as the full activities for their guidelines is another reason why they could not mobilize freely although they feel threatened like NU.

In contrast, the establishment of NU in Java in the 1920s was to resist "the plan of Saudi Arabia, guided by Wahhabi ideology, to destroy graves and other cultural traditions in Mecca and Medina." By respecting the

\footnotetext{
${ }^{34}$ Ahmad Najib Burhani, "Pluralism, Liberalism, and Islamism: Religious Outlook of Muhammadiyah”, Studia Islamika, Vol.25 No.23, 2018, 436-437.
} 
culture and its locality, NU then combines between Islamic values and their Indonesian culture and social heritage. To strengthen their identities, their idea of developing Islam Nusantara since 2015 has previously been taken from Gus Dur's knowledge on the Pribumisasi Islam (indigenization of Islam) that was introduced in the 1980s and has become NU's people as the software to resist the Islamic trans ideology in Indonesia. The software then becomes their spirit to oppose and to fight against it as well as to provide such kind of the face of Islamic religious expression that could be adaptable with the Indonesian context, socially, culturally, and politically. ${ }^{35}$ Therefore, the response has a historical background in the past. It is also like body immunity through the establishment of Islam Nusantara as their software imaginatively in the current years. Besides, their background is mostly coming to the rural place geographically as the base of NU members, which is undoubtedly another factor to redefine their Islamic identity amidst the enforcement of the urbanization of Indonesia, while the Islamisation from the urban people challenges their Islamic identity.

The first thing they should do is strengthening their website, mainly NU Online, by improving the various of the contents and visualizing the pictures with an impressive design. Instead of asking for the highest payment, most of them work voluntarily with the spirit of fighting against the Wahabi ideology, although in the beginning, they had no strength of capability. According to Hamzah Sahal, the founder of Alif.id, to establish and to maintain the NU Online relies on the same vision with the networks and their dedications. ${ }^{36}$ After a few years of hard work, their website could surpass those Islamic websites after the long years of

${ }^{35}$ Ahmad Najib Burhani, "Islam Nusantara as A Promosing Response to Religious Intolerance and Radicalism”, Trends in Southeast Asia, 21, Iseas-Yusuf Ishak, Singapore, 2018,

${ }^{36}$ Hamzah Sahal, "Mengapa NU Online Mengalahkan Web-web Islam Puritan", in https://alif.id/read/hamzah-sahal/mengapa-nu-online-mengalahkan-web-web-islam-puritanb214962p/, accessed in 18 July 2019. 
domination in the Google search engine. Not only are they strengthening their Islamic website, they have also created the two Islamic websites to challenges those of the new religious authorities collectively, mainly Islami. co, and BincangSyariah.com. Surprisingly, NU Online stands at the first position surpassing mulism.or.id and almanhaj.or.id. Meanwhile, their new Islamic websites steeply come into the 20 ranks, mainly Islami.co in the number of 10 ranks, and Bincangsyariah.com in the name of 16 levels.

\section{Bibliography}

Arifianto, Alexander, "Nadhlatul Ulama is home to its own hardliners", New Mandala, (8 August 2018), in http://www.newmandala.org/nadhlatululama-home-hardliners/, accessed 2 July 2019.

Arifianto, Alexander, "Quo Vadis Civil Islam? Explaining Rising Islamism in

Post-Reformasi Indonesia", in https://kyotoreview.org/issue-24/risingislamism-in-post-reformasi-indonesia/, accessed 25 June 2019.

Barendregt, Bart, "Mobile Religiosity in Indonesia: Mobilized Islam, Islamized Mobility and the Potential of Islamic Techno Nationalism", in Erwin Alampay (ed.). Living the Information Society in Asia. Singapore: ISEAS, 2009: 73-92.

Baulch, Emma and Pramiyanti Alilla, "Hijabers on Instagram: Using Visual Social Media to Construct the Ideal Muslim", Social Media + Society (2018): 1-15. Bräuchler, Birgit, "Cyber Identities at War: Religion, Identity, and the Internet in the Moluccan Conflict", Indonesia 75 (2003): 123-151.

Brown, Gustav, "Civic Islam: Muhammadiyah, NU and the Organisational Logic of Consensus-making in Indonesia", Asian Studies Review (2019): 1-18.

Bruinessen, Martin Van. Contemporary Developments in Indonesian Islam, Explaining the Conservative Turn. Singapore: ISEAS, 2013.

Burhani, Ahmad Najib, "Islam Nusantara as A Promosing Response to Religious Intolerance and Radicalism”, Trends in Southeast Asia, 21 (2018): 1-29.

Burhani, Ahmad Najib, "Plural Islam and Contestation of Religious Authority in Indonesia", in Islam in Southeast Asia: Negotiating Modernity, Noorshahril Saat (ed.). Singapore: ISEAS, 2018: 140-163.

Burhani, Ahmad Najib, "Pluralism, Liberalism, and Islamism: Religious Outlook of Muhammadiyah", Studia Islamika, Vol.25 No.23 (2018): 433-470.

Bush, Robin, "A Snapshot of Muhammadiyah Social Change and Shifting 
Markers of Identity and Values”, Asia Research Institute, Working Paper Series, No. 221 (2014).

CNN Indonesia, "GP Ansor Tolak Ceramah Ustaz Khalid di Masjid Hasyim Asyari”, in https://www.cnnindonesia.com/nasional/20180505105126-20-295900/ gp-ansor-tolak-ceramah-ustaz-khalid-di-masjid-hasyim-asyari?, accessed 16 July 2019.

CNN Indonesia, "Anak Muda Hijrah di mata NU dan Muhammadiyah", in https://www.cnnindonesia.com/nasional/20190516190532-20-395594/ anak-muda-hijrah-di-mata-nu-dan-muhammadiyah, accessed in 18 July 2019.

CNN Indonesia.com, "Muhammadiyah Imbau Masyarakat Tak Ikut Aksi 212", in https://www.cnnindonesia.com/nasional/20170220084040-20194629/ muhammadiyah-imbau-masyarakat-tak-ikut-aksi-212, accessed 1 July 2019. Detik.com, "Felix Siauw Bicara Soal Kajiannya Yang Dibatalkan Pemprov DKI", in https://news.detik.com/berita/d-4600270/felix-siauw-bicara-soal-kajiannyayang-dibatalkan-pemprov-dki, accessed 16 July 2019.

Duta Islam, "Provokatif, Ceramah Khalid Basalamah Ditolak Umat Islam Lamongan”, in https://www.dutaislam.com/2016/09/provokatif-ceramahkhalid-basalamah-ditolak-umat-islam-lamongan.html?hl=in_ID, accessed 16 July 2019.

Eickelman, Dale F. and Anderson, Jon W, "Redefining Muslim Publics", in Eickelman, Dale F and Anderson, Jon W (eds.). New Media in the Muslim World: The Emerging Public Sphere. Bloomington and Indianapolis: Indiana University Press, 2003.

Sahal, Hamzah, "Mengapa NU Online Mengalahkan Web-web Islam Puritan", in https://alif.id/read/hamzah-sahal/mengapa-nu-online-mengalahkanweb-web-islam-puritan-b214962p/, , accessed in 18 July 2019.

Ali, Hasanuddin, "Menakar Jumlah Jamaah NU dan Muhamamdiyah" in https://hasanuddinali.com/2017/01/19/menakar-jumlah-jamaah-nu-danmuhammadiyah/, accessed 17 July 2019.

Hefner, Robert W. Civil Islam: Muslim and Democractization in Indonesia. Pricenton: Princenton University Press, 2000.

Hosen, Nadirsyah, "Online Fatwa in Indonesia: From Fatwa Shopping to Googling a Kiai”, In Greg Fealy and Sally White (eds). Expressing Islam: Religious Life and Politics in Indonesia. Singapore: ISEAS, 2008: 159-173.

Kumparan, "Kronologi Penolakan Ustaz Hanan Attaki di Tegal oleh GP Ansor", in https://kumparan.com/panturapost/kronologi-penolakan-ustaz-hananattaki-di-tegal-oleh-gp-ansor-1rQGcF7kxIM, accessed 16 July 2019. 
Kumparan.com, "Tanggapan Felix Siauw Ditolak 5 Ormas di Semarang”, in https://kumparan.com/@kumparannews/tanggapan-felix-siauw-ditolak5-ormas-di-semarang, accessed 16 July 2019.

Lim, Merlyna, "Archipelago Online: The Internet and Political Activism in Indonesia", Doctoral Dissertation. University of Twente, The Netherlands, 2005.

Lim, Merlyna, "Cyber Urban”, In Anthony M Orum (ed), The Wiley Blackwell Encyclopedia of Urban and Regional Studies, New Jersey: Wiley Blackwell, 2019.

Lim, Merlyna, "Freedom to hate: social media, algorithmic enclaves, and the rise of tribal nationalism in Indonesia", Critical Asian Studies, Vol. 49, No. 3 (2017): 411-427.

Menchik, Jeremy, "Moderate Muslim and Democractic Breakdown", Asian Studies Review, vol. 43, no. 2 (2019): 415-433.

Muhammadiyah, "Data Amal Usaha Muhammadiyah", in http://www. muhammadiyah.or.id/id/content-8-det-amal-usaha.html, accessed 17 July 2019.

Mujiburrahman. Feeling Threatened: Muslim-Christian Relations in Indonesia's New Order. Amsterdam: Amsterdam University Press, 2006.

Muslim, Acep, "Digital Religion and Religious Life in Southeast Asia: the One Day One Juz (ODOJ) Community in Indonesia", Asianscape: Digital Asia, 4 (2017): 33-51.

Nadzir, Ibnu, "Da'wa 2.0: The Mediation of Preachingon Salafi's Internet Practices", paper presented on the conference "Religious Authority in Indonesian Islam: Contestation, Pluralization, and New Actors", ISEASYusuf Ishak, Singapore, 3-4 July 2018.

Nisa, Eva F, "Creative and Lucrative Da'wa: The Visual Culture of Instagram amongst Female Muslim Youth in Indonesia", Asiascape: Digital Asia, 5 (2018): 68-99.

NU Online, "Ini Penyebab Ceramah Khalid Basalamah Ditolak di Sidoarjo", in http://www.nu.or.id/post/read/75865/ini-penyebab-ceramah-khalidbasalamah-ditolak-di-sidoarjo-, accessed 16 July 2019.

NU Online, "Kemandirian Pendidikan NU", in http://www.nu.or.id/post/ $\mathrm{read} / 77580 /$ kemandirian-pendidikan-nu, accessed 17 July 2019.

Okezone.com, "Tanggapi Aksi 212, Said Aqil: Boleh Ikut Tapi Jangan Bawa Atribut NU", in https://news.okezone.com/read/2017/02/20/337/1623385/ tanggapi-aksi-212-said-aqil-boleh-ikut-tapi-jangan-bawa-atribut-nu, accessed 1 July 2019.

Pimpinan Wilayah Muhammadiyah Jawa Timur, Daftar Website Terafiliasi 
Persyarikatan Muhammadiyah”, in https://pwmu.co/daftar-websiteterafiliasi-persyarikatan-muhammadiyah/, accessed in 18 July 2019.

Repubika.co.id, "PBNU Terbitkan Fatwa Larangan Salat Jumat di Jalan Raya", in https://www.republika.co.id/berita/nasional/umum/16/11/24/ oh4wqf382-pbnu-terbitkan-fatwa-larangan-shalat-jumat-di-jalan-raya, accessed 1 July 2019.

Republika.co.id, "Mu'ti: Hijrah Fest Fenomena Sosial Keagamaan Yang Menarik", in https://www.republika.co.id/berita/dunia-islam/islamnusantara/18/11/12/pi2hxl384-muti-hijrah-fest-fenomena-sosialkeagamaan-yang-menarik, accessed in 18 July 2019.

Republika.co.id, "Sasar Milennial, Muhammadiyah Perkuat Konten Dakwah Digital”, in https://khazanah.republika.co.id/berita/dunia-islam/islamnusantara/19/02/15/pmz1ly320-sasar-milenial-muhammadiyah-perkuatkonten-dakwah-digital, accessed in 18 July 2019.

Republika.co.id, "Sasar Milennial, Muhammadiyah Perkuat Konten Dakwah Digital”, in https://khazanah.republika.co.id/berita/dunia-islam/islamnusantara/19/02/15/pmz1ly320-sasar-milenial-muhammadiyah-perkuatkonten-dakwah-digital, accessed in 18 July 2019.

Ricklefs, MC. Islamisation and Its Opponents in Java: A Political, Social, Cultural and Religious History, c. 1930 to Present. Singpore: NUS Press, 2012.

Setiawan, Benni, "Dakwah Pencerahan Era Digital", in https://investor.id/ archive/dakwah-pencerahan-era-digital, accessed 16 July 2019.

Slama, Martin, "A subtle economy of time : Social media and the transformation of Indonesia's Islamic Preacher Economy”, Economic Anthropology, 4 (2017): 94-106.

Thoyibi, M and Khisbiyah, Yayah (ed.). Kontestasi Wacana Keislaman di Dunia Maya: Moderatisme, Ekstremisme, dan Hipernasionalisme. Solo: Pusat Studi dan Perubahan Sosial UMS, 2018.

Tribunnews.com, "Ditolak Keras Salah Satu Ormas Terbesar, Felix Siauw Curhat Saat Hadir di Ponpes Al-Ikhlas Lamongan", in https://www.tribunnews. com/regional/2019/06/28/ditolak-keras-salah-satu-ormas-terbesar-felixsiauw-curhat-saat-hadir-di-ponpes-al-ikhlas-lamongan, accessed 16 July 2019.

Zaenuddin, Ahmad, "Kompetisi di antara berbagai situsweb Islam”, in https:// tirto.id/kompetisi-di-antara-berbagai-situsweb-islam-cEHi, accessed 17 July 2019. 